\title{
A comparison of rapid bioassessment protocols used in 2 regions with Mediterranean climates, the Iberian Peninsula and South Africa
}

\author{
Núria Bonada ${ }^{\mathbf{1}}$ \\ Department of Ecology, University of Barcelona, 08028 Barcelona, Spain \\ Helen Dallas ${ }^{2}$ \\ Freshwater Research Unit, Department of Zoology, University of Cape Town, Private Bag Rondebosch, \\ 7700 South Africa \\ Maria Rieradevall ${ }^{3}$ AND Narcís Prat ${ }^{4}$ \\ Department of Ecology, University of Barcelona, 08028 Barcelona, Spain \\ Jenny Day ${ }^{5}$ \\ Freshwater Research Unit, Department of Zoology, University of Cape Town, Private Bag Rondebosch, \\ 7700 South Africa
}

\begin{abstract}
The ability of 2 Rapid Bioassessment Protocols (RBPs) to assess stream water quality was compared in 2 Mediterranean-climate regions. The most commonly used RBPs in South Africa (SAprotocol) and the Iberian Peninsula (IB-protocol) are both multihabitat, field-based methods that use macroinvertebrates. Both methods use preassigned sensitivity weightings to calculate metrics and biotic indices. The SA- and IB-protocols differ with respect to sampling equipment (mesh size: $1000 \mu \mathrm{m}$ vs $250-$ $300 \mu \mathrm{m}$, respectively), segregation of habitats (substrate vs flow-type), and sampling and sorting procedures (variable time and intensity). Sampling was undertaken at 6 sites in South Africa and 5 sites in the Iberian Peninsula. Forty-four and 51 macroinvertebrate families were recorded in South Africa and the Iberian Peninsula, respectively; $77.3 \%$ of South African families and 74.5\% of Iberian Peninsula families were found using both protocols. Estimates of community similarity compared between the 2 protocols were $>60 \%$ similar among sites in South Africa and $>54 \%$ similar among sites in the Iberian Peninsula (Bray-Curtis similarity), and no significant differences were found between protocols (Multiresponse Permutation Procedure). Ordination based on Non-metric Multidimensional Scaling grouped macroinvertebrate samples on the basis of site rather than protocol. Biotic indices generated with the 2 protocols at each site did not differ. Thus, both RBPs produced equivalent results, and both were able to distinguish between biotic communities (mountain streams vs foothills) and detect water-quality impairment, regardless of differences in sampling equipment, segregation of habitats, and sampling and sorting procedures. Our results indicate that sampling a single habitat may be sufficient for assessing water quality, but a multihabitat approach to sampling is recommended where intrinsic variability of macroinvertebrate assemblages is high (e.g., in undisturbed sites in regions with Mediterranean climates). The RBP of choice should depend on whether the objective is routine biomonitoring of water quality or autecological or faunistic studies.
\end{abstract}

Key words: bioassessment, protocol, RBP, macroinvertebrates, water quality, Mediterranean rivers.

\footnotetext{
${ }^{1}$ Current address: Université Claude Bernard Lyon 1, CNRS-Ecologie des Hydrosystèmes Fluviaux, F-69622 Villeurbanne Cedex, France. E-mail: nuria.bonada@univ-lyon1.fr

2 E-mail addresses: hdallas@botzoo.uct.ac.za

3 mrieradevall@ub.edu

4 nprat@ub.edu

5 jday@botzoo.uct.ac.za
}

Rapid Bioassessment Protocols (RBPs) have been used widely to assess biological river quality (Wright et al. 1984, Plafkin et al. 1989, Davies 1994, Chessman 1995, Growns et al. 1995, Chutter 1998, Tiller and Metzeling 1998, Barbour et al. 1999). All RBPs aim to be efficient, effective, low in cost, and easy to use (Resh and Jackson 1993, Lenat and Barbour 1994, Resh et al. 
1995), but significant differences exist among the sampling protocols and metrics used. Biotic indices are the most widely used (e.g., Washington 1984) of the many metrics for evaluation of stream condition (Kerans et al. 1992, Lenat and Barbour 1994, Resh 1994, Resh et al. 1995, Gibson et al. 1996). Biotic indices have several shortcomings when used to assess water quality (Washington 1984, Norris and Georges 1993), but they have been used commonly, and they are highly robust, sensitive, cost-effective, easy to apply, and easy to interpret (Dallas 1995, 1997, Chessman et al. 1997).

Periphyton, macroinvertebrates, and fish all have been used to assess water quality (Plafkin et al. 1989, Barbour et al. 1999). Macroinvertebrates are the most commonly used organisms (Rosenberg and Resh 1993), and several biotic indices are based on this group (e.g., Chessman 1995, Chutter 1998, Wright 1995). Indices rely on sampling protocols that may differ with respect to equipment used, habitats sampled, sampling intensity, or processing of samples. In general, qualitative or semiquantitative sampling is undertaken (Lenat and Barbour 1994). One key difference among protocols is the habitat or habitats sampled. Some RBPs recommend sampling the most diverse habitat (Plafkin et al. 1989), but the most diverse habitat is not always the one most susceptible to anthropogenic impacts, nor is the most diverse habitat always evident. Other RBPs emphasize sampling in all available habitats (Kerans et al. 1992, Resh et al. 1995, Dallas 2000, 2002, 2004).

Sample processing also varies considerably among protocols, and the relative merits of field- vs laboratory-based processing, taxonomic resolution, and fractions to be sorted are much debated (Carter and Resh 2001). In field-based methods, macroinvertebrates normally are identified to family level (Chutter 1998, Prat et al. 2000). Taxonomic resolution to genus or species may yield greater precision and information (Furse et al. 1984, Resh et al. 1995, Stubauer and Moog 2000, Bailey et al. 2001, Lenat and Resh 2001), but family-level data may show patterns of community distribution that are similar to patterns based on genus- or species-level data (Furse et al. 1984, Ferrano and Cole 1992, Rutt et al. 1993, Marchant et al. 1995, Bowman and Bailey 1997, Nielsen et al. 1998). Therefore, numerous biotic indices use family-level taxonomic resolution because of its simplicity and costeffectiveness (Armitage et al. 1983, Hilsenhoff 1988, Alba-Tercedor and Sánchez-Ortega 1988, Chutter 1998, Prat et al. 1999, 2000).

Comparing biotic indices generated from different protocols may not be valid because different sampling protocols may have different biases (Erman 1981,
Kerans et al. 1992, Diamond et al. 1996). Several authors have compared the ability of different sampling techniques and metrics to assess water quality (e.g., Barton and Metcalfe-Smith 1992, Kerans et al. 1992). However, most such attempts are focused in a specific region and, thus, do not test the applicability of the technique or metric in other regions. The aim of our study was to compare the ability of 2 RBPs to assess water quality of streams in 2 regions with Mediterranean climate. We used the SA-protocol, developed in South Africa and based on version 5 of the South African Scoring System (SASS5; Dickens and Graham 2002) and the IB-protocol, developed in the Iberian Peninsula (Iberian Biological Monitoring Working Party [IBMWP], formerly BMWP'; AlbaTercedor and Sánchez-Ortega 1988, Alba-Tercedor et al. 2002). Both RBPs are multihabitat, field-based methods that require identification of macroinvertebrates to family level. For each, sensitivity weightings, which have been preassigned to individual taxa based on their tolerance to water-quality impairment, are used to calculate biotic indices. In this respect, the biotic indices from SASS5 and IBMWP are analogous to the Biological Monitoring Working Party (BMWP) scores used in the UK (Armitage et al. 1983). SA- and IB-protocols differ with respect to sampling equipment used (mesh size), segregation of habitats, and sampling and sorting procedures. Both RBPs have been applied extensively in their respective countries and are sensitive to water-quality impairment (Camargo 1993, Dallas 1995, 1997, Zamora-Muñoz et al. 1995, Zamora-Muñoz and Alba-Tercedor 1996, García-Criado et al. 1999, Prat et al. 1999, Alba-Tercedor and Pujante 2000). Our study is a comparative one designed to examine the interregional applicability of RBPs in Mediterranean-climate regions. It further aims to discuss the implications of differences in protocols for bioassessment in general.

\section{Methods}

\section{Study area}

The Cape region, South Africa, and Catalonia, Iberian Peninsula, are in Mediterranean regions, the climate of which is defined in terms of precipitation (di Castri 1973) and temperature (Aschmann 1973) with hot, dry summers and cool, wet winters. Consequently, Mediterranean-climate rivers are subject to a natural flow disturbance resulting in seasonal floods and droughts (Gasith and Resh 1999). Macroinvertebrates were sampled at 11 sites, 6 in the Cape region and 5 in Catalonia. Sampling was undertaken simultaneously by 2 of the authors (HD and NB, respectively), who used both protocols in both regions. 
TABLE 1. Geographical, physical, and chemical characteristics of the rivers sampled in South Africa and the Iberian Peninsula. $-=$ data not available.

\begin{tabular}{|c|c|c|c|c|c|c|c|c|c|}
\hline River & Category & Code & $\begin{array}{l}\text { Altitude } \\
\text { (m asl) }\end{array}$ & $\begin{array}{c}\text { Stream } \\
\text { order } \\
(1: 250,000)\end{array}$ & $\begin{array}{c}\text { Conductivity } \\
(\mu S / \mathrm{cm})\end{array}$ & $\begin{array}{c}\text { Temperature } \\
\left({ }^{\circ} \mathrm{C}\right)\end{array}$ & $\mathrm{pH}$ & \multicolumn{2}{|r|}{$\mathrm{O}_{2}$} \\
\hline \multicolumn{10}{|l|}{ Eerste Basin } \\
\hline Erste & Mountain stream & EM & 390 & 2 & 27.1 & 15.8 & 6.35 & 9.52 & 93.1 \\
\hline Swartboskloof & Mountain stream & SW & 390 & 1 & 25.1 & 15.7 & 5.93 & 7.50 & 75.5 \\
\hline Eerste foothill & Foothill stream & $\mathrm{EC}$ & 170 & 3 & 74.9 & 20.0 & 6.78 & 8.15 & 85.4 \\
\hline \multicolumn{10}{|l|}{ Palmiet Basin } \\
\hline Palmiet transitional & Foothill stream & PA & 50 & 5 & 102.2 & 20.3 & 6.39 & 9.21 & 96.3 \\
\hline \multicolumn{10}{|l|}{ Iberian Peninsula } \\
\hline \multicolumn{10}{|l|}{ Besòs Basin } \\
\hline Gallifa & Mountain stream & B24 & 560 & 1 & 695.0 & 11.3 & 8.35 & 10.07 & 96.4 \\
\hline Montsant & Foothill stream & MONT & 530 & 2 & - & - & - & - & - \\
\hline
\end{tabular}

Sampling was conducted in spring (October 2001 in South Africa and April 2002 in the Iberian Peninsula).

South African sites.-Five sites in the Eerste River basin and 1 in the Palmiet River basin (Table 1, Fig. 1A) were sampled. Four of the Eerste River basin sites were relatively pristine mountain streams (Langrivier [LA], Sosyskloof [SO], Swartboskloof [SW], and Eerste [EM]) and 1 was an impacted Eerste foothill site $[E C])$. A $6^{\text {th }}$ site (PA) was sampled in the Kogelberg Nature Reserve in the Palmiet River basin. PA is a $5^{\text {th }}$-order stream, but it is a rejuvenated foothill stream and is considered an ecologically important reference site. PA also was included as an opportunity to test the RBPs at a site that was different from the other Cape region sites. The vegetation at all sites in the South African Mediterranean-climate region was dominated by mountain fynbos, with Metrosideros angustifolia (blackwood) or Brabejum stellatifolium (wild almond) in the riparian area and Prionium serratum (palmiet) on river banks, although some introduced trees occurred at EC (Acacia melonoxylon, Quercus robur [common oak]). Mountain stream sites and PA had brown, acidic, and oligotrophic waters, whereas EC had slightly higher $\mathrm{pH}$ and conductivity and received significant agricultural runoff (Brown and Dallas 1995). The substratum was dominated by boulders, large cobbles, and bedrock in the mountain streams and cobbles, pebbles, and coarse sand downstream. Algae were scarce in such acidic conditions, although some macrophytes and mosses were abundant as instream vegetation in the lotic habitats of SW, EM, and PA.
Iberian Peninsula sites.-Five sites from the Besòs and Siurana basins (Table 1, Fig. 1B) were sampled. Gallifa (B24), Tenes (B28, B25), and Ripoll (B22) are tributaries of the Besòs River and have a calcareous and sedimentary geology. Most of the water comes from Sant Llorenç Natural Park, but only B24 and B28 can be considered mountain streams; in these sites, the basin is forested with sclerophyllous Mediterranean forest and riparian vegetation dominated by Salix alba (white willow), Coryllus avellana (hazelnut), Populus nigra (black poplar), and Populus alba (white poplar). Downstream, in the foothill areas (B22 and B25), the basin has been altered significantly by anthropogenic activity, which has affected water quality and riparian vegetation (e.g., presence of introduced species such as Platanus hispanica [plane tree], Populus deltoides [cottonwood], and Robinia pseudoacacia [black locust]; Prat et al. 1999). The Montsant River (MONT) is a tributary of the Siurana River (tributary of the Ebre River) that flows through Montsant Natural Park, an area with predominantly calcareous geology. MONT and B24 are considered near-pristine sites in contrast to B22, B25, and B28, which are affected by human disturbances (Prat et al. 1999). In general, all sites presented instream vegetation dominated by mosses, diatoms, Zygnematales and Cladophora spp., whereas macrophytes, primarily Apium nodiflorum (fools watercress) or Veronica spp. (speedwell), are dominant in the river channel. Channel substratum is composed of bedrock, large stones, and sand in mountain streams and bedrock, pebbles, and coarse sand in foothill streams. 


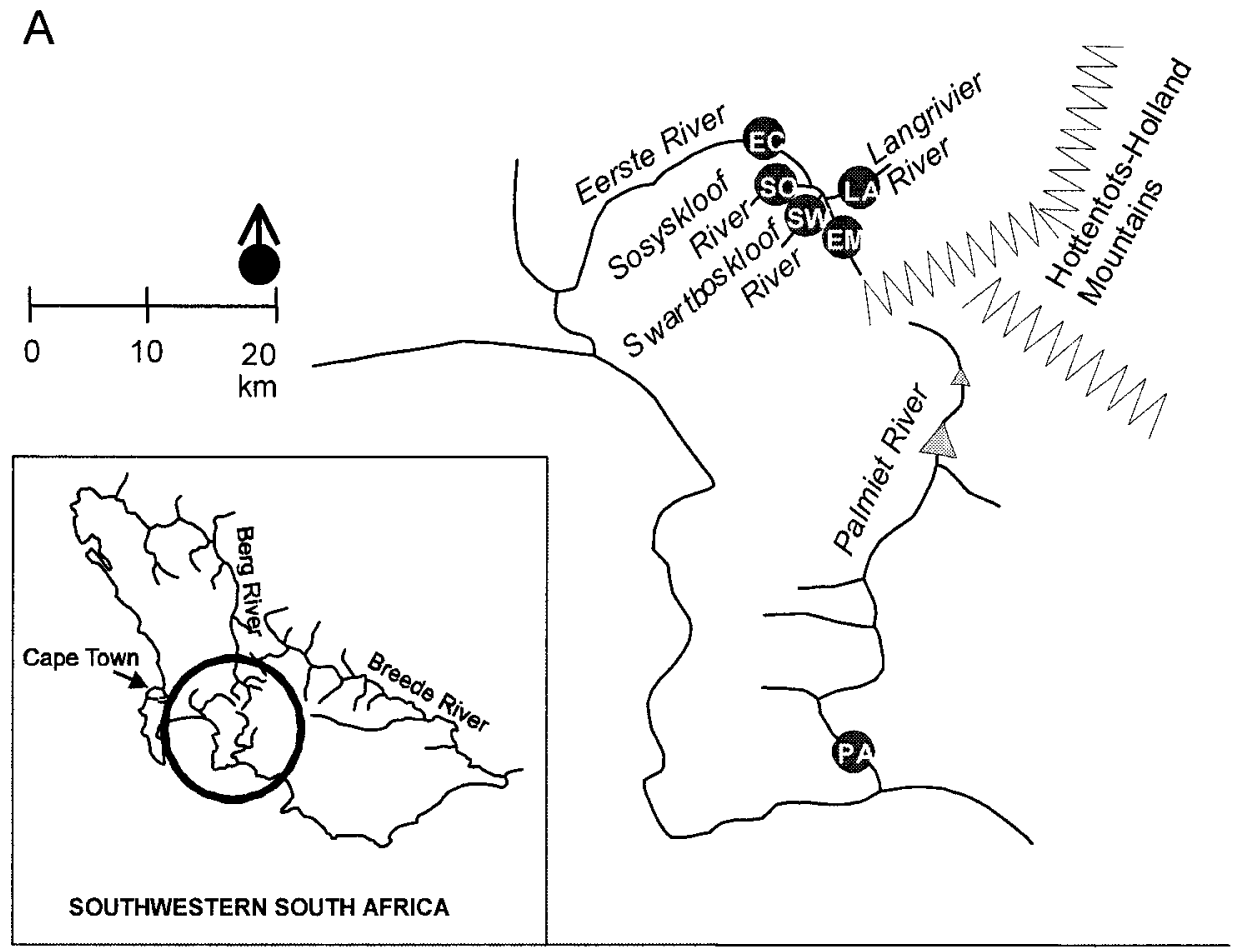

B

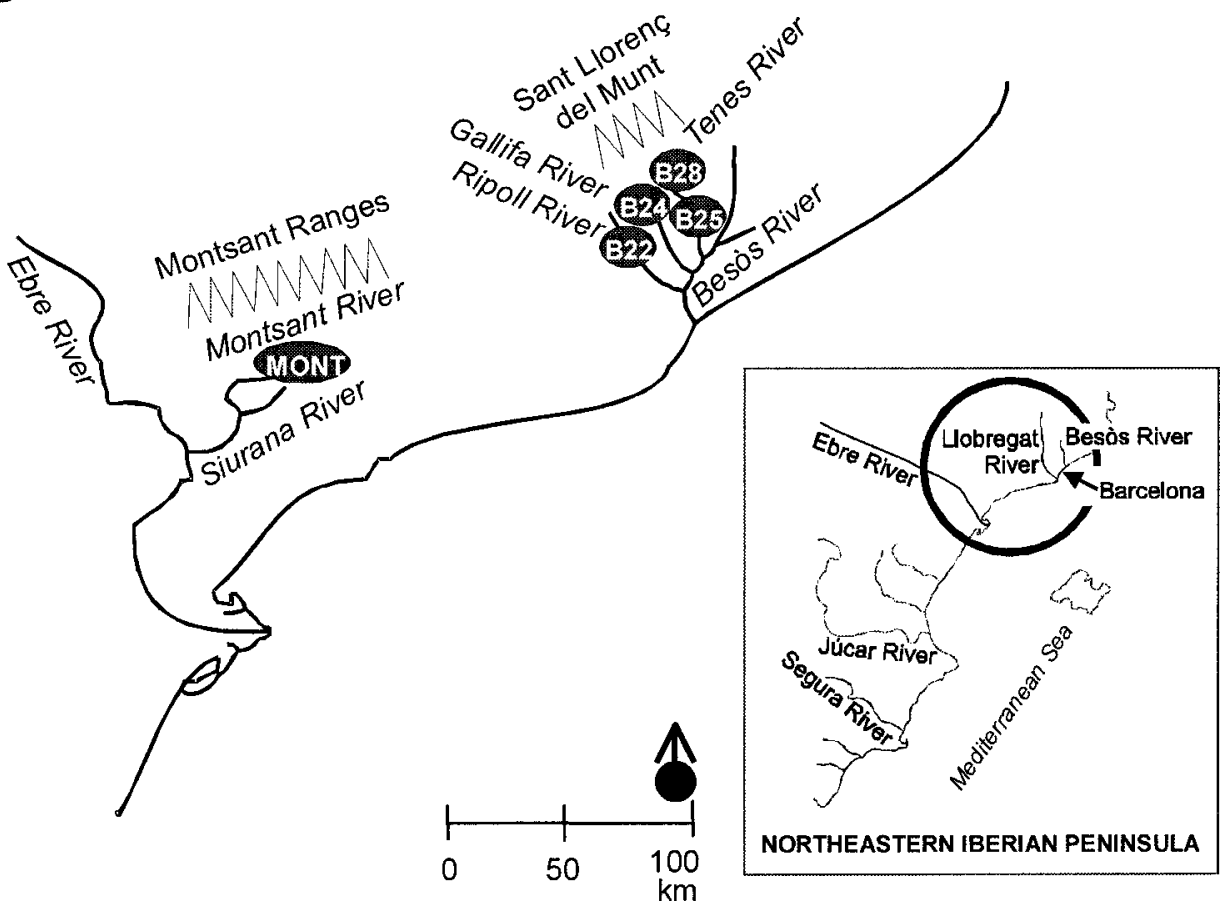

FIG. 1. Locations of sampling sites in South Africa (A) and the Iberian Peninsula (B). Arrows in boxes indicate main urban areas. River codes as in Table 1. 


\section{Sampling protocols}

SA-protocol (Dickens and Graham 2002).-A kick-net $(30 \times 30 \mathrm{~cm}, 1000-\mu \mathrm{m}$-mesh size) was used to sample all available habitats, grouped as follows: stones (S), vegetation $(\mathrm{V})$, and sand. $S$ habitat included stones-incurrent and stones-out-of-current; $\mathrm{V}$ included marginal and instream vegetation (Fig. 2). Sand was not present at any sites. Stones-in-current were kicked for $\sim 2 \mathrm{~min}$ if all were loose and for $5 \mathrm{~min}$ if some were immovable. Loose substratum was agitated, and dislodged organisms were collected downstream in the net. Stones-out-of-current were sampled by kicking an area of $\sim 1 \mathrm{~m}^{2}$; dislodged organisms were collected by sweeping the net over the stones. Marginal vegetation was swept for a distance of $\sim 2 \mathrm{~m}$, and instream vegetation was sampled by dislodging organisms in $\sim 1 \mathrm{~m}^{2}$ of vegetated habitat. Collected material was emptied into separate trays for each habitat type (S and V); debris was removed, and organisms were identified to the appropriate taxonomic level according to the SA-protocol (mostly family, except for Hydracarina and Oligochaeta, and Hydropsychidae and Baetidae, for which the number of species/types were recorded). Each sample was searched for the shorter of either $15 \mathrm{~min}$ or until $5 \mathrm{~min}$ had passed since a new family had been found. Organisms (e.g., Heteroptera) not collected, but seen in the field, also were included in the calculation of the index. Abundances were estimated semiquantitatively according to the following ranks: $1=1$ individual, $2=2$ to 10 individuals, $3=10$ to 100 individuals, $4=100$ to 1000 individuals, $5=\geq 1000$ individuals. The SAprotocol generates 3 values: the biotic index called the SASS5 score (SA-score), the number of taxa (T), and the Average Score per Taxon (SA-score/T $=\mathrm{SA} / \mathrm{T}$ score) (Table 2, Fig. 2). These values were obtained per habitat ( $\mathrm{S}$ and V separately) and per site ( $\mathrm{S}$ and V together $=\mathrm{SV}$ ). The SA-score is calculated by summing the sensitivity weightings (tolerance scores) of the taxa present in a sample. Data are interpreted using existing tables of habitat-quality classes that have been derived for mountain and foothill streams of the Cape region (Dallas 2002, 2004). Interpretation is based on both the SA-score and the SA/T-score as follows: reference $=$ SA-score $>140, \mathrm{SA} / \mathrm{T}$-score $>8.0$; below reference $=$ SA-score between 100 and 139, SA/T-score between 7.0 and 8.0; well below reference $=\mathrm{SA}$-score between 60 and 99, SA/T-score between 6.0 and 6.9; and impoverished $=\mathrm{SA}$-score $<60, \mathrm{SA} / \mathrm{T}$-score $<6.0$.

IB-protocol (Prat et al. 2000, Jáimez-Cuéllar et al. 2002).- A kick net (250- $\mu \mathrm{m}$-mesh size) was used to sample all available habitats, usually grouped as lotic (riffles and runs [R]) and lentic (L) (Prat et al. 2000; Fig.
2). In $R$ habitats, the net was positioned downstream of the stones, which were agitated and cleaned, to collect dislodged organisms. The process was repeated until several stones were sampled or the net became clogged. In L habitats, marginal vegetation, gravel, and mud were swept. Collected material was emptied into trays and separated by habitat type; debris was removed, and organisms were identified to family level (except for Hydracarina, Oligochaeta, and Ostracoda). The process was repeated until no new taxa were recorded. Organisms not collected, but seen in the field (e.g., Heteroptera), also were included in the calculation of the index. Abundances were estimated semiquantitatively according to the following ranks: 1 $=1$ to 3 individuals, $2=4$ to 10 individuals, $3=11$ to 100 individuals, $4=\geq 100$ individuals. The IB-protocol generates 3 values: the biotic index called IBMWP (IBscore), the number of taxa (T), and the Average Score per Taxon (IB-score/T $=\mathrm{IB} / \mathrm{T}$-score) (Alba-Tercedor and Sánchez-Ortega 1988, Alba-Tercedor and Pujante 2000, Alba-Tercedor et al. 2002; Table 2, Fig. 2). Scores were calculated per habitat ( $\mathrm{R}$ and $\mathrm{L}$ separately) and per site ( $R$ and $L$ together $=\mathrm{RL}$ ). Like the SA-score, the IB-score is calculated by summing the sensitivity weightings (tolerance scores) of the taxa present in a sample. This score ranges from 0 to $>100$, and interpretation is as follows: very good quality = IBscore $>100$, good quality $=$ IB-score between 61 and 100, fair quality $=$ IB-score between 36 and 60, bad quality $=$ IB-score between 16 and 35 , and very bad quality $=$ IB-score $<15$.

Application of protocols to the sampling regions.-The SA-protocol is focused on differences among physical substrates (i.e., $\mathrm{S}$ vs V), whereas the IB-protocol uses flow-type to separate different habitats (i.e., R vs L; Table 2). The high degree of similarity between the SAscore and the IB-score allowed us to calculate either biotic index using either protocol (Fig. 2). However, each index was designed originally based on regional taxa and tolerances. Therefore, both protocols were used in both regions, but the SA-score was calculated for the South African data sets and the IB-score was calculated for the Iberian Peninsula data sets.

\section{Data analysis}

Similarities and differences in macroinvertebrate communities among sites and RBPs were assessed using Non-metric Multidimensional Scaling (NMDS), applied to the site $\times$ taxon abundance matrix. This ordination method preserves the distances between objects, plotting dissimilar objects far from the similar ones (Legendre and Legendre 1998). The NMDS method is not based on eigenvalues, so final axes are 


\section{Sampling protocols}

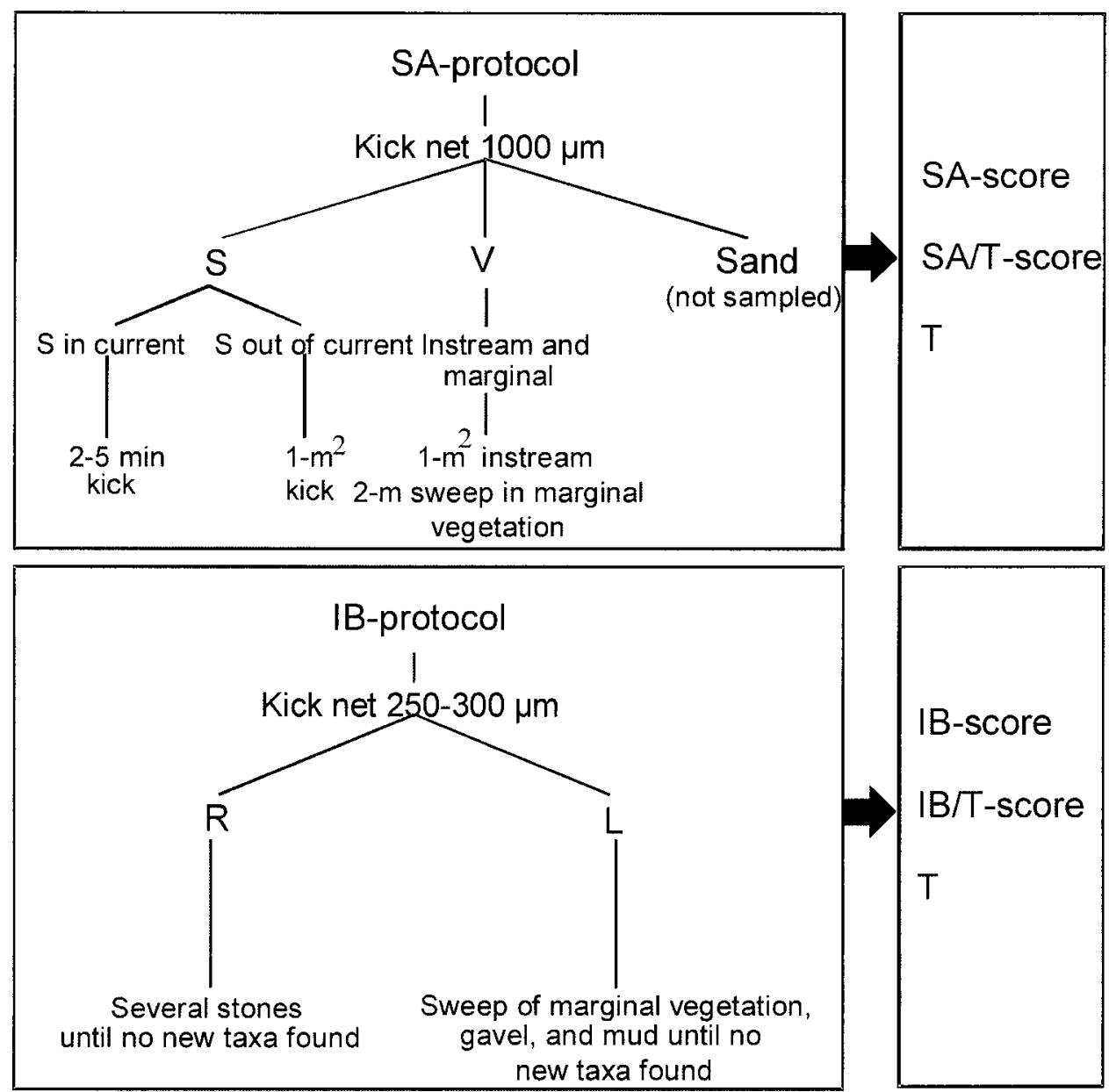

FIG. 2. Sampling procedures for the Iberian Biological Monitoring Working Party (IBMWP) and version 5 of the South African Scoring System (SASS5) protocols (IB- and SA-protocols) and the metrics generated for each. $S=$ stones, $V=$ vegetation, $\mathrm{R}=$ riffles $/$ runs, $\mathrm{L}=$ lentic. Metric abbreviations are as in Table 2.

TABLE 2. Comparison of the South African (SA) and Iberian (IB) protocols, considering the items proposed by Resh et al. (1995). $\mathrm{T}=$ number of taxa, SA-score $=$ score based on version 5 of the South African Scoring System (SASS5), SA/T-score $=$ average SA/T, IB-score $=$ score based on the Iberian Biological Monitoring Working Party (IBMWP) index, IB/T-score $=$ average IB-score/T (see text for details of scores and score abbreviations).

\begin{tabular}{lll}
\hline \hline Consideration & \multicolumn{1}{c}{ South African protocol } & Iberian Peninsula protocol \\
\hline Habitats to be examined & All habitats, separated by physical substrates & All habitats, separated by flow type \\
Sampling area and intensity & 100-m reach & 100-m reach \\
Sampling intensity & Standardized by time or area, depending & Until no more new taxa are found \\
& on the habitat & Kick net \\
Sampling devices & Kick net & $250-300 \mu \mathrm{m}$ \\
Mesh sizes & $1000 \mu \mathrm{m}$ & All \\
Proportion examined & Time- and taxon-dependent & Mostly family \\
Taxonomic level & Mostly family (genus for Baetidae and & T, IB-score, IB/T-score \\
Metrics & Hydropsychidae) & Samples from reference sites \\
Quality control and assurance & T, SA-score, SA/T-score & (Bonada et al. 2002) \\
\hline
\end{tabular}


arbitrary without enclosing the explained variability. The Bray-Curtis coefficient was selected to calculate distances between variables and \% similarities between sites. The statistical significance of differences in macroinvertebrate assemblages recorded using the 2 RBPs was tested with a nonparametric Multiresponse Permutation Procedure (MRPP) test. This analysis tests multivariate differences among predefined groups (RL vs SV) providing the statistic $A$ and a $p$-value obtained by permutation (999 runs). This nonparametric method is more appropriate than multiple analysis of variance for comparisons of data matrices that involve species abundances with many 0 values. Differences between biotic indices and metrics were tested using nonparametric Kruskal-Wallis tests. PCORD (version 4.20, MjM Software, Gleneden Beach, California) and STATISTICA (release 5.5, Stat Soft, Tulsa, Oklahoma) were used to run the analyses.

\section{Results \\ Macroinvertebrate assemblages}

Forty-four families of macroinvertebrates were recorded in South Africa and 51 families were recorded in the Iberian Peninsula. The number of taxa collected using both SA and IB protocols was high (77.3\% [34 families] in South Africa and 74.5\% [38 families] in the Iberian Peninsula; Table 3). Some families in the Iberian Peninsula and South Africa were collected using only one protocol or the other (Table 3) but, in spite of these differences, Bray-Curtis similarities between protocols were relatively high, ranging from 54.2 to $74.2 \%$ in the Iberian Peninsula and from 60.8 to $73.2 \%$ in South Africa. Mean BrayCurtis similarities among 21 minimally disturbed reference sites in mountain streams of the Cape region, South Africa, was 49\%, indicating that intrinsic variability is very high in these sites (Dallas 2002). In our study, similarities among minimally disturbed mountain stream sites in South Africa $(n=4)$ ranged between $55.6 \%$ and $74.7 \%$ (SA-protocol) and between $48.2 \%$ and $79.2 \%$ (IB-protocol). Similarities between the minimally disturbed mountain stream sites and the disturbed foothill site ranged from $40.0 \%$ to $47.3 \%$ (SAprotocol) and between $36.4 \%$ and $45.6 \%$ (IB-protocol). These results suggest that both RBPs reflected a decrease in similarity between sites as disturbance (pollution) increases and as one moves longitudinally down the river. In the Iberian Peninsula, where sites were more disturbed than in South Africa, similarities between sites ranged from $28.0 \%$ to $54.0 \%$ (SAprotocol) and $26.7 \%$ and $61.8 \%$ (IB-protocol). Both RBPs identified the same most-similar and leastsimilar sites in both South Africa and the Iberian
Peninsula. The degree of similarity, as reflected by Bray-Curtis similarity, between the RBPs did not seem to be related to the degree of disturbance.

The NMDS analysis (Fig. 3A, B) indicated that both RBPs distinguished between mountain stream sites and foothill stream sites. NMDS grouped sites on the basis of location rather than on the basis of protocol (i.e., samples from the same site but collected with different protocols grouped together). In South Africa, similarities assessed with SA and IB protocols were greatest among mountain stream sites (Fig. 3A). Both protocols identified the Palmiet River site as having a unique macroinvertebrate community. The high degree of similarity between methods was confirmed by the MRPP analysis indicating nonsignificant differences between samples within sites collected with IBprotocols and SA-protocols in the Iberian Peninsula $(A$ $=-0.021, p=0.6814)$ and in South Africa $(A=-0.0293$, $p=0.792)$.

\section{Metrics and indices}

Similarities between protocols were also apparent when values of the biotic indices and metrics were examined (Table 4, Fig. 4A-F). SA-scores and IB-scores (Fig. 4A, D), numbers of taxa (Fig. 4B, E), and SA/Tscores and IB/T-scores (Fig. 4C, F) did not differ between samples collected under different protocols within sites in either region (Table 4), indicating that both RBPs produced equivalent results at the site level (i.e., when data from both habitats were combined). No significant differences between protocols were found for any metric when individual habitats in the Iberian Peninsula were compared, indicating that, in general, sampling only one habitat $(\mathrm{R}, \mathrm{L}, \mathrm{S}$, or V) would be enough to obtain a reliable biotic index (Table 4). In contrast, SA-score and number of taxa showed significant differences between habitats in South Africa, especially S vs V and L vs S (Table 4). Generally, $\mathrm{S}$ and $\mathrm{R}$ habitats had higher SA-scores and numbers of taxa than V and L habitats (Fig. 4D, E), and contributed more to the overall site scores than $\mathrm{V}$ and $\mathrm{L}$ habitats. These regional differences in metrics calculated for different habitats may be attributed to a different proportion of undisturbed vs disturbed sites sampled in each region.

\section{Comparison of regions}

Sampling sites in the Iberian Peninsula generally had lower IB-scores and IB/T-scores than sites in South Africa, regardless of whether the SA-protocol or IB-protocol was applied (Fig. 4). Sites in the Iberian Peninsula had a mean IB-score of $73.5 \pm 13.5$ with the IB-protocol and $64.5 \pm 17.3$ with the SA-protocol. The 
TABLE 3. Macroinvertebrate families (in alphabetical order) recorded by version 5 of the South African Scoring System (SASS5) and Iberian Biological Monitoring Working Party (IBMWP) protocols (SA- and IB-protocols) in 2 Mediterranean-climate regions, the Cape region of South Africa and Catalonia on the Iberian Peninsula. Sensitivity weightings for the SA-score in South Africa and IBscore in the Iberian Peninsula are in parentheses. Values range from 1 to 15 in SA and from 1 (tolerant) to 10 (sensitive) in IB. (na) = nonassigned value, introduced family.

\begin{tabular}{|c|c|c|c|}
\hline IB-protocol only & SA-protocol only & \multicolumn{2}{|c|}{ Both protocols } \\
\hline \multicolumn{4}{|l|}{ South Africa } \\
\hline Aeschnidae (8) & Gerridae (5) & Baetidae (4-12) & Hydracarina (8) \\
\hline Belostomatidae (3) & Protoneuridae (8) & Blephariceridae (15) & Hydropsychidae (4-12) \\
\hline Heptageniidae (13) & & Caenidae (6) & Leptoceridae (6) \\
\hline Hydroptilidae (6) & & Ceratopogonidae (5) & Leptophlebiidae (9) \\
\hline & & Corydalidae (8) & Notonemouridae (14) \\
\hline & & Dixidae (10) & Oligochaeta (1) \\
\hline & & Dugesiidae (3) & Petrothrincidae (11) \\
\hline & & Dytiscidae (5) & Philopotamidae (10) \\
\hline & & Ecnomidae (8) & Pisuliidae (10) \\
\hline & & Elmidae (8) & Simuliidae (5) \\
\hline Ancylidae (6) & Cambaridae (na) & Aeschnidae (8) & Hydraenidae (5) \\
\hline Dixidae (4) & Gammaridae (6) & Asellidae (3) & Hydrobiidae (3) \\
\hline Hydroptilidae (6) & Helodidae (3) & Baetidae (4) & Hydrometridae (3) \\
\hline Libellulidae (8) & Veliidae (3) & Bythinellidae (3) & Hydrophilidae (3) \\
\hline Lymnaeidae (3) & & Caenidae (4) & Hydropsychidae (5) \\
\hline Planorbidae (3) & & Calopterygidae (8) & Leptoceridae (10) \\
\hline Polycentropodidae (7) & & Ceratopogonidae (4) & Leptophlebiidae (10) \\
\hline Psychodidae (4) & & Chironomidae (2) & Limnephilidae (7) \\
\hline Stratiomyidae (4) & & Coenagrionidae (6) & Naucoridae (3) \\
\hline & & Corixidae (3) & Nemouridae (7) \\
\hline & & Culicidae (2) & Nepidae (3) \\
\hline & & Dytiscidae (3) & Oligochaeta (1) \\
\hline
\end{tabular}

single exception was MONT (IB-score $=171$ [IBprotocol] and 136 [SA-protocol]). However, the IB/Tscore was not able to discriminate MONT from the more disturbed sites (mean values of $4.56 \pm 0.5$ with IB-protocol and $4.67 \pm 0.5$ with SA-protocol). In general, and especially for the MONT site, the IBprotocol produced higher IB-scores and numbers of taxa than the SA-protocol in the Iberian Peninsula, but not in South Africa.

Only one site in South Africa (EC) had reduced water quality (SA-score $=56$ [SA-protocol] and 54 [IBprotocol]), whereas the mean SA-score of the rest of the South African sampling sites was $161.4 \pm 14.2$ with the SA-protocol and $165.4 \pm 15.2$ with the IBprotocol. Values of the SA/T-score differed between the more-disturbed EC site and the rest of the sites using both protocols (SA/T-score for $\mathrm{EC}=4.7$ and 4.5 using SA- and IB-protocols, respectively; mean SA/Tscore for the undisturbed sites $=7.7 \pm 0.7$ and $9.1 \pm$ 0.9 using SA- and IB-protocols, respectively). Different proportions of undisturbed and more disturbed sites were sampled in South Africa and in the Iberian Peninsula, but both protocols applied in both areas were able to separate sites having different waterquality conditions. 


\section{Discussion}

\section{Comparability of RBPs}

Two RBPs, applied to the same sets of sites in 2 different Mediterranean-climate regions, had comparable ability to distinguish among biotic communities and detect water-quality impairment. More disturbed sites were sampled in the Iberian Peninsula than in South Africa, but both protocols produced similar results and distinguished between sites with high and low water quality. Our results suggest that RBPs may differ in terms of sampling method, equipment, subsampling, taxonomic resolution, metrics, and index calculation, but still may yield comparable results depending on the objectives of the survey (Diamond et al. 1996). The degree of comparability between methods is usually unknown because few direct comparisons have been made (Diamond et al. 1996).

\section{Influence of specific sampling differences between RBPs}

Most RBPs use kick or sweep nets for sampling macroinvertebrates, although mesh size of the net often varies from $250 \mu \mathrm{m}$ to $1000 \mu \mathrm{m}$. In our study, the 2 RBPs used nets with mesh sizes at either end of this spectrum, and our results suggest that differences in mesh size did not mask differences between sites. However, the influence of mesh size on taxa collected may vary seasonally in response to differences in lifehistory stages of different taxa. For example, insects in temporary streams are usually smaller in size, so the use of a different mesh size could affect the final results, especially following a drought (Williams 1996).

The South African protocol standardizes sampling effort by setting stringent guidelines on the basis of sampling period (e.g., $2 \mathrm{~min}$ for loose stones-in-current) or area sampled (e.g., $1 \mathrm{~m}^{2}$ for stones-out-of-current). Sample sorting continues until no new taxa are recorded. In contrast, both sampling and sorting in the Iberian protocol continue until no new taxa are recorded. These differences in sampling and sorting efforts between the protocols did not affect the biotic indices calculated in our study. However, the objectives of a study are important in determining the approach used. We recommend standardized sampling and sorting (such as is used in SA-protocol) for routine monitoring or bioassessment, which often has both time and financial constraints, and the goal of which often is for the sampling to act as a red flag for water-quality impairment. However, if the objectives go beyond bioassessment to autecological or faunistic studies, then the IB-protocol may be have advantages over the SAprotocol because a more complete representation of the community, including rare taxa, is provided.

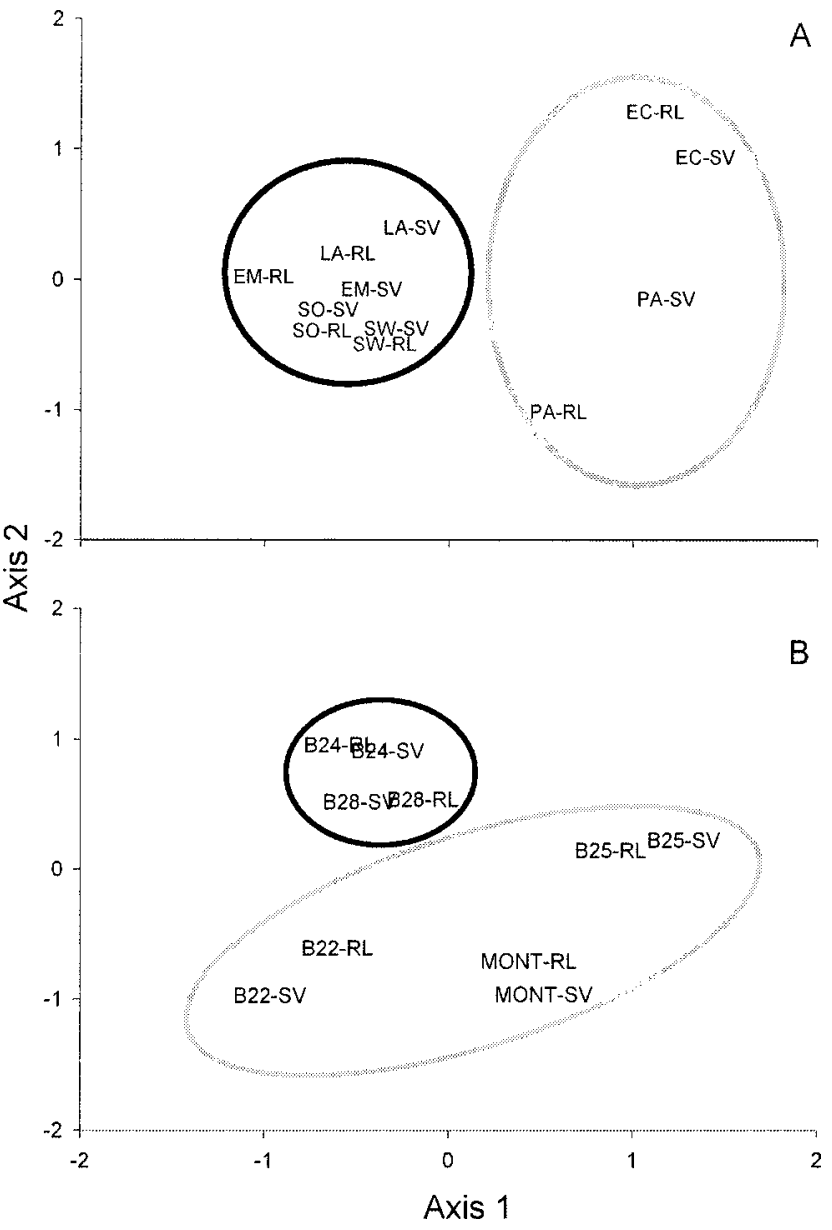

FIG. 3. Non-metric Multidimensional Scaling scores for sites in South Africa (A) and the Iberian Peninsula (B) using both protocols in each region. SV following the site code refers to data obtained with the South African protocol and RL refers to data obtained using the Iberian protocol (see text for details). Black circles indicate mountain stream sites; grey circles indicate foothill stream sites. Site codes as in Table 1 and Fig. 1.

\section{Effect of RBP on metrics and indices}

Increased sampling effort is likely to increase the total number of taxa recorded, as well as the number of rare taxa recorded. Variation in taxon richness between RBPs, specifically the higher number of taxa collected and higher IB-score obtained when using the IBprotocol in the Iberian Peninsula (Fig. 4), may have been related to the familiarity of each researcher with the macroinvertebrate fauna of her respective country and to the higher sensitivity weighting of some families found only using the IB-protocol (e.g., Polycentropodidae and Libellulidae, Table 3). In general, the taxa not recorded were either rare (e.g., Dixidae, Belostomatidae, and Psychodidae) or were recorded at 
TABLE 4. $H$ statistic and $p$-values of the Kruskal-Wallis nonparametric tests comparing version 5 of the South African Scoring System (SASS5) and Iberian Biological Monitoring Working Party (IBMWP) protocols (SA- and IB-protocols) and habitats in South Africa and the Iberian Peninsula. Stones (S) and vegetation (V) were sampled in the SA-protocol and riffles/runs (R) and lentic (L) habitats were sampled in the IB-protocol. Samples from R and L (RL) and S and V (SV) were combined for the comparison of SAand IB-protocols. $\mathrm{T}=$ number of taxa, SA-score $=$ score based on version 5 of the South African Scoring System (SASS5), SA/T score $=$ average SA/T, IB-score = score based on the Iberian Biological Monitoring Working Party (IBMWP) index, IB/T-score $=$ average IB-score/T (see text for details of scores and score abbreviations). Bold font indicates a significant difference at $p<0.05$.

\begin{tabular}{|c|c|c|c|c|c|c|c|c|c|c|c|c|}
\hline \multirow[b]{2}{*}{ Comparison } & \multicolumn{6}{|c|}{ South Africa } & \multicolumn{6}{|c|}{ Iberian Peninsula } \\
\hline & $H$ & $p$ & $H$ & $p$ & $H$ & $p$ & $H$ & $p$ & $H$ & $p$ & $H$ & $p$ \\
\hline RL vs SV & 0.411 & 0.521 & 2.129 & 0.145 & 2.077 & 0.150 & 0.237 & 0.601 & 0.905 & 0.341 & 0.273 & 0.602 \\
\hline$R$ vs $S$ & 1.641 & 0.200 & 3.169 & 0.075 & 0.025 & 0.873 & 1.320 & 0.250 & 1.104 & 0.293 & 0.011 & 0.917 \\
\hline $\mathrm{R}$ vs $\mathrm{V}$ & 3.330 & 0.068 & 4.866 & 0.027 & 2.133 & 0.144 & 1.320 & 0.250 & 0.889 & 0.345 & 0.534 & 0.465 \\
\hline $\mathrm{R}$ vs $\mathrm{L}$ & 3.102 & 0.078 & 4.122 & 0.042 & 2.564 & 0.109 & 0.889 & 0.345 & 0.711 & 0.399 & 2.454 & 0.117 \\
\hline $\mathrm{S}$ vs $\mathrm{V}$ & 4.799 & 0.028 & 6.593 & 0.010 & 1.200 & 0.273 & 0.098 & 0.754 & 0.011 & 0.916 & 0.273 & 0.601 \\
\hline
\end{tabular}

very low abundances throughout the sampling period (e.g., Ancylidae, Gammaridae, Heptageniidae, Gerridae, and Hydroptilidae in the Iberian Peninsula). Further, our results showed differences in taxon richness between habitats in South Africa but not in the Iberian Peninsula. This difference may be a reflection of the greater number of undisturbed sites sampled in South Africa relative to the Iberian Peninsula. These undisturbed sites have higher intrinsic spatial heterogeneity than more disturbed sites (Dallas 1995, 2002, 2004).

\section{Spatial and temporal variability in habitats}

The key difference between the RBPs was the segregation of habitats, specifically separation on the basis of substrate (SA-protocol) vs flow type (IBprotocol). The kind and number of habitats to be sampled in a RBP have been widely debated (Resh et al. 1995, Hewlett 2000). Our study suggests that, in undisturbed sites, $\mathrm{R}$ or $\mathrm{S}$ habitats had higher values for taxon richness and a higher biotic index than $\mathrm{L}$ or $\mathrm{V}$ habitats (Fig. 4). This result has been observed previously (Dallas 2002, 2004), and the suggestion that sampling in riffles alone may be sufficient (Parsons and Norris 1996) should be considered. On the other hand, in more disturbed sites, sampling any habitat could provide a reliable value of the general water quality of the site because no differences in taxa richness and biotic index were found between habitats. However, the high seasonal variability in flow of Mediterranean-climate rivers means that riffles may disappear temporarily with only pools remaining in summer (Gasith and Resh 1999). Other systems, such as many lowland rivers, do not have riffle habitats present at any time of year. Thus, sampling based on riffles alone would be impossible. Furthermore, the relative importance of different habitats may vary seasonally, longitudinally down a river, and regionally (Dallas 2002, 2004). Therefore, the use of only one habitat in streams with high temporal and spatial variability in habitat availability cannot be recommended, and a multihabitat protocol that integrates all available habitats, as in both tested protocols, is preferred.

Different habitats also may be more or less vulnerable to anthropogenic disturbance. This differential vulnerability is a further reason to adopt a multihabitat approach to bioassessment in Mediterranean-climate rivers and streams. In our comparison of biotic indices calculated for individual habitats, values of biotic indices declined in $\mathrm{R}$ and $\mathrm{S}$ habitats in more disturbed sites (all samples in the Iberian Peninsula except for MONT and only the EC site for South Africa; Fig. 4), whereas values of biotic indices in $\mathrm{L}$ and $\mathrm{V}$ habitats remained relatively constant. This result suggests that $\mathrm{R}$ and $\mathrm{S}$ habitats are more affected by anthropogenic activities than $\mathrm{L}$ and $\mathrm{V}$ habitats, a result supported by recent work in other Mediterraneanclimate rivers (Solà 2004). However, Logan and Brooker (1983) pointed out that the effect of pollution by solids was greater in pools than in riffles, and they suggested using both habitats to assess water quality.

\section{Recommendations}

In conclusion, a time-saving protocol intended for routine monitoring of water quality (SA protocol) produced results similar to those produced by a more comprehensive protocol (IB protocol) when applied in 

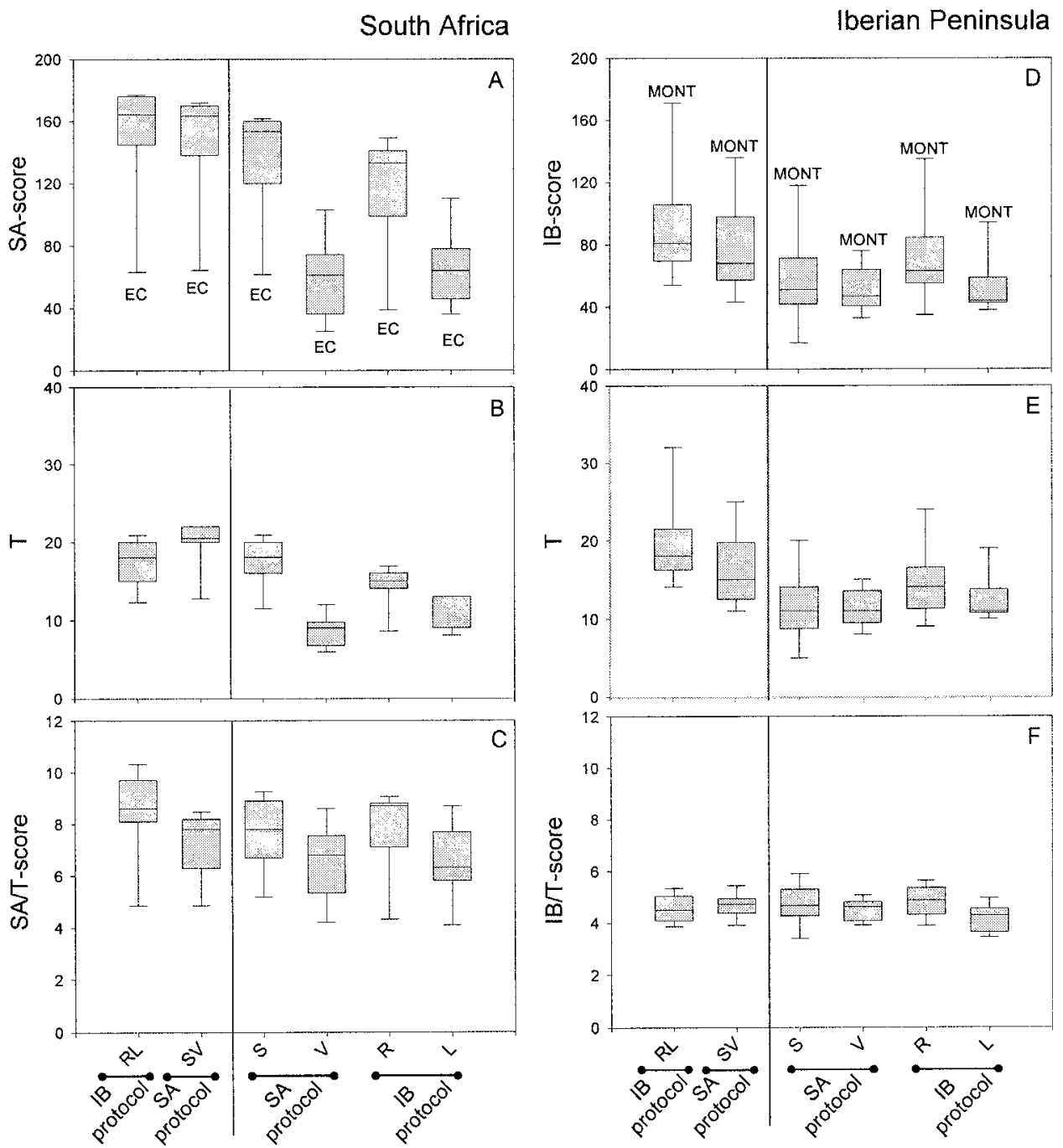

FIG. 4. Box-and-whisker plots of SA-scores (A), number of taxa (T; B), and SA/T-scores (C) for habitats in sites sampled using the SA- and IB-protocols in South Africa and IB-scores (D), number of taxa (T; E), and IB/T-scores (F) for habitats in sites sampled using IB- and SA-protocols on the Iberian Peninsula. Stones (S) and vegetation (V) habitats were sampled in South Africa and riffles/runs (R) and lentic (L) habitats were sampled on the Iberian Peninsula. The line in each box shows the median value of the metric. Tops and bottoms of boxes are the $75^{\text {th }}$ and $25^{\text {th }}$ percentiles, respectively. Whiskers show $10^{\text {th }}$ and $90^{\text {th }}$ percentiles for each metric. Site abbreviations (Table 1, Fig. 1) above or below whiskers indicate outliers relative to other sites in the region. Vertical lines inside each plot separate results per site (SV and RL for the SA- and IB-protocols, respectively) and per habitat (S and V for SA-protocol and R and L for IB-protocol). Metric abbreviations as in Table 2.

South Africa and the Iberian Peninsula. Both South Africa and the Iberian Peninsula are developing frameworks that use these RBPs in the context of reference conditions. The River Health Program in South Africa and the application of the Water Frame Directive in the Iberian Peninsula are based on assessment of environmental status using reference conditions. Both RBPs compared in our paper are or can be incorporated usefully into these programs, which are designed to ensure appropriate management of aquatic ecosystems.
The SA- and IB-protocols were designed to be applied in Mediterranean-climate rivers, where river conditions have high spatial and temporal variability (Bonada 2003). However, in a broader context, both RBPs also could be used and (possibly) simplified in other areas, depending on the purposes of the study and the environmental characteristics of the region. Most of these considerations deal with habitat selection and adaptation of sensitivity weightings, used to calculate the biotic indices, to the tolerance range of each family in the area. In general, a multihabitat 
approach is always recommended in Mediterraneanclimate rivers and streams but, in other areas with low temporal variability, unihabitat methods could provide reliable biotic indices. In that sense, riffles or stones are more susceptible to disturbance than pools or vegetation and, therefore, either one is recommended for assessing the most general impacts on rivers. Furthermore, when a new protocol to assess water quality is applied in a new area, special care should be taken to validate the sensitivity weightings assigned to each family in each region. This validation is particularly important in areas with a large number of species because the degree of tolerance at the family level may depend on diversity of species and the tolerance ranges of individual species.

\section{Acknowledgements}

This research was supported by the GUADALMED Project (HID98-0323-C05 and REN2001-3438-C07) and a grant to NB from the Ministerio de Ciencia y Tecnología. Special thanks to members of the Freshwater Research Unit, University of Cape Town and colleagues from the ECOBILL project, University of Barcelona, for their ongoing support and friendship. We also thank Martin Gurtz and 2 anonymous referees for their comments on the manuscript.

\section{Literature Cited}

Alba-Tercedor, J., P. Jáimez-Cuéllar, M. Álvarez, J. Avilés, N. Bonada, J. Casas, A. Mellado, M. Ortega, I. Pardo, N. Prat, M. Rieradevall, S. Robles, C. Sáinz-Cantero, A. Sánchez-Ortega, M. L. Suárez, M. Toro, M. R. VidalAbarca, S. Vivas, AND C. ZAMORA-MuÑOZ. 2002. Caracterización del estado ecológico de ríos mediterráneos ibéricos mediante el índice IBMWP (antes BMWP'). Limnetica 21:175-185.

Alba-Tercedor, J., AND A. Pujante. 2000. Running-water biomonitoring in Spain. Opportunities for a predictive approach. Pages 207-216 in J. F. Wright, D. W. Sutcliffe, and M. T. Furse (editors). Assessing the biological quality of fresh waters. RIVPACS and other techniques. Freshwater Biological Association, Ambleside, UK.

Alba-Tercedor, J., AND A. SÁnchez-OrtegA. 1988. Un método rápido y simple para evaluar la calidad biológica de las aguas corrientes basado en el de Hellawell (1978). Limnetica 4:51-56.

Armitage, P. D., D. Moss, J. F. Wright, and M. T. Furse. 1983. The performance of a new biological water quality score system based on macroinvertebrates over a wide range of unpolluted running water sites. Water Research 17: 333-347.

AschmanN, H. 1973. Distribution and peculiarity of Mediterranean ecosystems. Pages 11-19 in F. di Castri and H. A. Mooney (editors). Mediterranean type ecosystems: origin and structure. Springer-Verlag, New York.
Bailey, R. C., R. H. Norris, and T. B. Reynoldson. 2001. Taxonomic resolution of benthic macroinvertebrate communities in bioassessments. Journal of the North American Benthological Society 20:280-286.

Barbour, M. T., J. Gerritsen, B. D. SNYder, AND J. B. Stribling. 1999. Rapid bioassessment protocols for use in streams and wadeable rivers: periphyton, benthic macroinvertebrates and fish. $2^{\text {nd }}$ edition. EPA 841-B-99-002. Office of Water, US Environmental Protection Agency, Washington, DC.

Barton, D. R., And J. L. Metcalfe-Smith. 1992. A comparison of sampling techniques and summary indices for assessment of water quality in the Yamaska River, Québec, based on benthic macroinvertebrates. Environmental Monitoring and Assessment 21:225-244.

BONADA, N. 2003. Ecology of the macroinvertebrate communities in mediterranean rivers at different scales and organization levels. PhD Dissertation, University of Barcelona, Barcelona, Spain. (Available from: http:// www.tdx.cbuc.es/)

Bonada, N., N. Prat, A. Munné, M. Rieradevall, J. AlbaTercedor, M. Álvarez, J. Avilés, J. Casas, P. JáimezCuéllar, A. Mellado, G. Moyá, I. Pardo, S. Robles, G. Ramón, M. L. SuÁrez, M. Toro, M. R. Vidal-Abarca, S. Vivas, AND C. ZAMORA-MuÑoz. 2002. Criterios para la selección de condiciones de referencia en los ríos mediterráneos. Resultados del proyecto GUADALMED. Limnetica 21:99-114.

Bowman, M. F., AND R. C. Bailey. 1997. Does taxonomic resolution affect the multivariate description of the structure of freshwater benthic macroinvertebrate communities? Canadian Journal of Fisheries and Aquatic Sciences 54:1802-1807.

Brown, C. A., AND H. F. Dallas. 1995. Eerste River, Western Cape: situation assessment of the riverine ecosystem. Final Report. Southern Waters Ecological Research and Consulting, Cape Town, South Africa. (Available from: http:/ / www.admin@southernwaters.co.za)

CAmargo, J. A. 1993. Macrobenthic surveys as a valuable tool for assessing freshwater quality in the Iberian Peninsula. Environmental Monitoring and Assessment 24:71-90.

Carter, J. L., And V. H. Resh. 2001. After site selection and before data analysis: sampling, sorting, and laboratory procedures used in stream benthic macroinvertebrate monitoring programs by USA state agencies. Journal of the North American Benthological Society 20:658-682.

Chessman, B. C. 1995. Rapid river assessment using macroinvertebrates: a procedure based on habitat-specific family level identification and a biotic index. Australian Journal of Ecology 20:122-129.

Chessman, B. C., J. E. Growns, and A. R. Kotlash. 1997. Objective derivation of macroinvertebrate family sensitivity grade numbers for the SIGNAL biotic index: application to the Hunter River system, New South Wales. Australian Journal of Marine and Freshwater Research 48:159-172.

Chutter, F. M. 1998. Research on the rapid biological assessment of water quality impacts in streams and 
rivers. WRC Report No. 422/1/98. Water Research Commission, Pretoria, South Africa.

DAllas, H. F. 1995. An evaluation of SASS (South African Scoring System) as a tool for the rapid bioassessment of water quality. MSc Thesis, University of Cape Town, Cape Town, South Africa.

DALLAS, H. F. 1997. A preliminary evaluation of aspects of SASS (South African Scoring System) for the rapid bioassessment of water quality in rivers, with particular reference to the incorporation of SASS in a national biomonitoring programme. South African Journal of Aquatic Sciences 23:79-94.

Dallas, H. F. 2000. The derivation of ecological reference conditions for riverine macroinvertebrates. National Biomonitoring Programme for Riverine Ecosystems: Report Series No. 12. Institute for Water Quality Studies, Department of Water Affairs and Forestry, Pretoria, South Africa.

DALlas, H. F. 2002. Spatial and temporal heterogeneity in lotic systems: implications for defining reference conditions for riverine macroinvertebrates. PhD Dissertation, University of Cape Town, Cape Town, South Africa.

DALlas, H. F. 2004. Spatial and temporal heterogeneity in lotic systems: implications for defining reference conditions for riverine macroinvertebrates. Water Research Commission Report TT224/04. Water Research Commission, Pretoria, South Africa. (Available from http:// www.wrc.org.za/publications_reports.htm)

DAvies, P. E. 1994. National River Processes and Management Program Monitoring River Health Initiative. River Bioassessment Manual, version 1.0. Department of the Environment, Sport and Territories, Canberra. (Available from: http://www.deh.gov.au/water/rivers/nrhp/ bioassess.html)

DiAmond, J. M., M. T. BARbour, AND J. B. Stribling. 1996. Characterizing and comparing bioassessment methods and their results: a perspective. Journal of the North American Benthological Society 15:713-727.

DI CASTRI, F. 1973. Climatographical comparisons between Chile and the western coast of North America. Pages 2136 in F. di Castri and H. A. Mooney (editors). Mediterranean type ecosystems: origin and structure. Springer-Verlag, Berlin, Germany.

Dickens, C. W. S., and P. M. Graham. 2002. The South African Scoring System (SASS) version 5 rapid bioassessment method for rivers. African Journal of Aquatic Science 27: $1-10$.

ERMAN, D. C. 1981. Stream macroinvertebrate baseline surveys: a comparative analysis from the oilshale regions of Colorado, USA. Environmental Management 5:531536.

Ferrano, S. P., AND F. A. Cole. 1992. Taxonomic level sufficient for assessing a moderate impact on macrobenthic communities in Puget Sound, Washington, USA. Canadian Journal of Fisheries and Aquatic Sciences 49: 1184-1188.

Furse, M. T., D. Moss, J. F. Wright, And P. D. Armitage. 1984. The influence of seasonal and taxonomic factors on the ordination and classification of running-water sites in
Great Britain and on the prediction of their macroinvertebrate communities. Freshwater Biology 14:257280.

García-Criado, F., A. Tomé, F. J. Vega, and C. Antolín. 1999. Performance of some diversity and biotic indices in rivers affected by coal mining in northwestern Spain. Hydrobiologia 394:209-217.

Gasith, A., AND V. H. Resh. 1999. Streams in Mediterranean climate regions: abiotic influences and biotic responses to predictable seasonal events. Annual Review of Ecology and Systematics 30:51-81.

Gibson, G. R., M. T. BARbour, J. B. Stribling, J. Gerritsen, AND J. R. KARR. 1996. Biological criteria: technical guidance for streams and small rivers (revised edition). EPA-822-B94-001. Office of Water, US Environmental Protection Agency, Washington, DC.

Growns, J. E., B. C. Chessman, P. K. McEvor, And I. A. Wright. 1995. Rapid river assessment using macroinvertebrates: case studies in the Nepean River and Blue Mountains, NSW. Australian Journal of Ecology 20:130-141.

Hewlett, R. 2000. Implications of taxonomic resolution and sample habitat for stream classification at a broad geographic scale. Journal of the North American Benthological Society 19:352-361.

HilsenHOFF, W. L. 1988. Rapid field assessment of organic pollution with a family level biotic index. Journal of the North American Benthological Society 7:65-68.

Jáimez-Cuéllar, P., S. Vivas, N. Bonada, S. Robles, A. Mellado, M. Álvarez, J. Avilés, J. Casas, M. Ortega, I. Pardo, N. Prat, M. Rieradevall, C. Sáinz-Cantero, A. SÁnchez-Ortega, M. L. SuÁrez, M. Toro, M. R. VidalAbarca, C. Zamora-Muñoz, and J. Alba-Tercedor. 2002. Protocolo GUADALMED (PRECE). Limnetica 21:187204.

Kerans, B. L., J. R. Karr, and S. A. Ahlstedt. 1992. Aquatic invertebrate assemblages: spatial and temporal differences among sampling protocols. Journal of the North American Benthological Society 11:377-390.

LEGENDRE, P., AND L. LeGENDRE. 1998. Numerical ecology. $2^{\text {nd }}$ English edition. Developments in Environmental Modelling 20. Elsevier, Amsterdam, The Netherlands.

LENAT, D. R., AND M. T. BARBOUR. 1994. Using benthic macroinvertebrate community structure for rapid, costeffective, water quality monitoring: rapid bioassessment. Pages 187-215 in S. L. Loeb and A. Spacie (editors). Biological monitoring of aquatic systems. Lewis Publishers, Boca Raton, Florida.

Lenat, D. R., and V. H. Resh. 2001. Taxonomy and stream ecology-The benefits of genus- and species-level identifications. Journal of the North American Benthological Society 20:287-298.

LogAn, P., AND M. P. BROOKER. 1983. The macroinvertebrate faunas of riffles and pools. Water Research 17:263-270.

Marchant, R., L. A. BarmutA, and B. C. Chessman. 1995. Preliminary study of the ordination of macroinvertebrate communities from running waters in Victoria, Australia. Australian Journal of Marine and Freshwater Research 45:945-962.

Nielsen, D. L., R. J. ShIEL, AND F. J. SMith. 1998. Ecology versus 
taxonomy: is there a middle ground? Hydrobiologia 387/388:451-457.

Norris, R. H., AND A. Georges. 1993. Analysis and interpretation of benthic macroinvertebrate surveys. Pages 234-286 in D. M. Rosenberg and V. H. Resh (editors). Freshwater biomonitoring and benthic macroinvertebrates. Chapman and Hall, New York.

PARSONS, M., AND R. H. NorRIs. 1996. The effects of habitatspecific sampling on biological assessment of water quality using a predictive model. Freshwater Biology 36: 419-434.

Plafkin, J. L., M. T. Barbour, K. D. Porter, S. K. Gross, And R. M. Hughes. 1989. Rapid bioassessment protocols for use in streams and rivers: benthic macroinvertebrates and fish. EPA/444/4-89-001. Office of Water Regulations and Standards, US Environmental Protection Agency, Washington, DC.

Prat, N., A. Munné, M. Rieradevall, C. Solà, and N. Bonada. 2000. ECOSTRIMED: protocol to establish the ecological status of Mediterranean rivers and streams. Diputació de Barcelona, Àrea de Medi Ambient, Barcelona, Spain. (Available from: http://www.diba.es/mediambient/ ecostrimed.asp)

Prat, N., M. Rieradevall, A. Munné, C. SolÀ, and N. Bonada. 1999. La qualitat ecològica del Llobregat, el Besòs i el Foix. Informe 1997. Diputació de Barcelona, Àrea de Medi Ambient, Barcelona, Spain. (Available from: http:/ / www.diba.es/mediambient/publquri.asp)

RESH, V. H. 1994. Variability, accuracy, and taxonomic costs of rapid assessment approaches in benthic macroinvertebrate monitoring. Bolletino di Zoologia 61:375-383.

Resh, V. H., AND J. K. JACKSON. 1993. Rapid assessment approaches to biomonitoring using benthic macroinvertebrates. Pages 195-233 in D. M. Rosenberg and V. H. Resh (editors). Freshwater biomonitoring and benthic macroinvertebrates. Chapman and Hall, New York.

Resh, V. H., R. H. Norris, AND M. T. BARbOUR. 1995. Design and implementation of rapid assessment approaches for water resource monitoring using benthic macroinvertebrates. Australian Journal of Ecology 20:108-121.

RosenberG, D. M., AND V. H. Resh. 1993. Introduction to freshwater biomonitoring and benthic macroinvertebrates. Pages 1-9 in D. M. Rosenberg and V. H. Resh (editors). Freshwater biomonitoring and benthic macroinvertebrates. Chapman and Hall, New York.

RutT, G. P., T. D. Pickering, AND N. R. M. Reynolds. 1993. The impact of livestock farming on Welsh streams: the development and testing of a rapid biological method for use in the assessment and control of organic pollution from farms. Environmental Pollution 81:217-228.

SolÀ, C. 2004. Impacte de l'accident miner d'Aznalcóllar sobre el riu Guadiamar. Recuperació de la comunitat de macroinvertebrats i bioacumulació de metalls pesants. $\mathrm{PhD}$ Thesis, University of Barcelona, Barcelona, Spain. (Available from: http://www.tdx.clouc.es/)

Stubauer, I., AND O. Moog. 2000. Taxonomic sufficiency versus need of information-comments based on the Austrian experiences in biological water quality monitoring. Verhandlungen der Internationalen Vereinigung für theoretische und angewandte Limnologie 27:25622566.

Tiller, D., AND L. H. Metzeling. 1998. Rapid bioassessment of Victorian streams. Environment Protection Authority, Melbourne, Australia. (Available from: http:// www.deh.gov.au/water/rivers/nrhp/manual-vic/)

Washington, H. G. 1984. Diversity, biotic and similarity indices. A review with special relevance to aquatic ecosystems. Water Research 18:653-694.

Williams, D. D. 1996. Environmental constraints in temporary waters and their consequences for the insect fauna. Journal of the North American Benthological Society 15: 634-650.

Wright, J. F. 1995. Development and use of a system for predicting the macroinvertebrate fauna in flowing waters. Australian Journal of Ecology 20:181-197.

Wright, J. F., D. Moss, P. D. Armitage, And M. T. Furse. 1984. A preliminary classification of running water sites in Great Britain based on macroinvertebrate species and the prediction of community type using environmental data. Freshwater Biology 14:221-256.

Zamora-Muñoz, C., ANd J. Alba-Tercedor. 1996. Bioassessment of organically polluted Spanish rivers, using a biotic index and multivariate methods. Journal of the North American Benthological Society 15:332-352.

Zamora-Muñoz, C., C. E. SÁinz-Cantero, A. Sánchez-Ortega, ANd J. Alba-Tercedor. 1995. Are biological indices $\mathrm{BMPW}^{\prime}$ and $\mathrm{ASPT}^{\prime}$ and their significance regarding water quality seasonally dependent? Factors explaining their variations. Water Research 29:285-290.

Received: 6 April 2004 Accepted: 27 December 2005 